\title{
Drafting a New Civil Code in the GDR: Stalinism
}

\author{
Martin Löhnig
}

Universität Regensburg, Fakultät für Rechtswissenschaft

E-mail: Martin.Loehnig@jura.uni-regensburg.de

\begin{abstract}
:
The first attempt of the GDR to enact a new Civil Code started in September 1952 and failed with the revolution in June 1953. The old laws were thought to disturb the consolidation of socialist legal order and hinder the development of full respect for laws and the development of a socialistic state and legal consciousness (Walter Ulbricht). In the archives we find minutes of proceedings and drafts of the first two chapters in the personal files of Hilde Benjamin. These drafts were strongly influenced by traditional civil law thinking under which all members of the commission had grown up.
\end{abstract}

\section{Keywords:}

Civil Code; Hans Nathan; Hilde Benjamin; GDR; Stalinism; socialist property

DOI: $10.14712 / 2464689 X .2019 .31$

\section{The External History of the Legislative Process}

In the German Democratic Republic (Deutsche Demokratische Republik, GDR) the Bürgerliche Gesetzbuch of 1 January 1900 (Civil Code, $B G B$ ) remained valid after 1945. Several attempts were made to establish a new Civil Code before finally, on 1 January 1976, the Zivilgesetzbuch der $D D R(Z G B)$, comprising 480 sections, came into force. However, only 15 years later, on 3 October 1990 it was substituted by the previous $B G B$, the same day that the territory of the GDR joined the jurisdiction of the Grundgesetz. The legislative history of the $Z G B$ reflects 30 years of political changes during the existence of the GDR. This can be shown by the fact that all obstacles to the development of a new Civil Code were political concerns. ${ }^{1}$ This also applies to the first attempt of the GDR to enact a new Civil Code that

Cf. ECKERT, J. Einleitende Bemerkungen zur Entstehungsgeschichte des ZGB der DDR. In: ECKERT, J. - HATTENHAUER, H. (eds.). Das Zivilgesetzbuch der DDR vom 19. Juni 1975. Goldbach: Keip Verlag, 1995, pp. 231 ss.; FLINDER, M. Die Entstehungsgeschichte des Zivilgesetzbuches der DDR. Frankfurt/ Main et al.: Peter Lang Verlag, 1999. 
would replace $B G B$ and Handelsgesetzbuch (commercial code, $H G B$ ). The failure of this project is related to the state crisis which culminated in the revolution of 17 June 1953.

The work began after decisions of the Sozialistische Einheitspartei Deutschlands (socialist party, SED) at their second conference in July $1952 .^{2}$ Walter Ulbricht, president of the Central Committee of the SED called the valid capitalistic law a barrier in the development of a new legal concept and demanded a draft of a Civil Code for the GDR. ${ }^{3}$ He expected this to aggravate the class struggle also in the field of the judiciary. Furthermore, some other "socialist brother countries" had already eliminated the capitalistic civil law by enacting new codes or had at least started working on new codes. In a meeting on September 22 in 1952 the Ministry of Justice set up a commission for the preparation of civil laws. The basis of the commission's work were procedural rules ${ }^{4}$ which obliged its members to maintain strict secrecy 5 and established almost conspiratorial codes of conduct concerning the handling of materialist files. They considered this necessary to ensure that the source of any files that fell into the hands of third parties was traceable. ${ }^{6}$ Indeed, in the years 1952 and 1953 it is likely that not much leaked out about the development of a Civil Code and its eventual failure. That's why there are no relevant reactions in the specialized newspapers of the former GDR (Staat und Recht and Neue Justiz).

Minutes of proceedings and decisions of the commission had not been passed on in the files of the Ministry of Justice of the GDR but simply in the files of the Oberster Gerichtshof (supreme court) of the GDR, specifically the personal files of Vice President Hilde Benjamin. This presents historians with the advantage that the handwritten marginal notes (and scribblings that were probably caused by boredom!) of this very influential GDR-jurist have been passed on.

The secrecy was probably motivated by an internal political agenda - a failure of the legislative process could have been seen as a setback for the building of socialism, but alternatively, by an agenda to produce political propaganda for the GDR and also of the USSR (Stalin Note) aimed at the building of a neutral pan-German state. The creation of a domestic Civil Code going hand in hand with the destruction of the, at least according to the letters, still extant legal unity between both German states would have impeded this aim. In the joint meeting of the general and sub-commission on December 8, 1952 comrade Otto was censured. In a meeting in the Amt zum Schutze des Volkseigentums (Office for the Protection of People's Property), where the question of ownership of garden plots had been discussed, he had pointed out that "according to the explanations of comrade Walter Ulbricht", a team for the preparation of new laws was convened to discuss a cover-up tactic. $^{7}$

2 Cf. ULBRICHT, W. Beschluß der II. Parteikonferenz der SED. Berlin: Dietz Verlag, 1952.

$3 \quad$ Neue Welt 1952, 1820.

4 Protokoll der Sitzung der Grundkommission von 22. September 1952, BA Berlin-Lichterfelde DP 2/5521 fol. $5 \mathrm{ff}$.

5 Protokoll der Sitzung der Grundkommission von 22. September 1952, BA Berlin-Lichterfelde DP 2/5521 fol. 6 .

6 BENJAMIN, H. Protokoll der Sitzung der Grundkommission von 22. September 1952, BA Berlin-Lichterfelde DP 2/5521 fol. 5 .

7 Protokoll der Grund- und Unterkommissionssitzung am 8. Dezember 1952, BA Berlin-Lichterfelde DP 2/5521 fol. 60 . 
Between 22 September 1952 and 4 May 1953 the basic commission and the subcommission met at regular intervals of one or two weeks. " A synoptic account of the law of the people's democracies and the Soviet Union" "was intended to build the basis for the work. However, it was never been written. Translations of different laws, however, can be found in the files. These are translations of the Civil Code of the USSR, with its related model contracts, the Civil Code of the ČSSR and the Romanian inheritance law. The materials from the work of the contemporaneous Polish Legislative Commission, however, cannot be found in the files.

The commission's members began to work out the chapters of the first three books in the form of "theses" with justifications for each, after they had reached an agreement on basic questions concerning the structure and content of the Civil Code. The theses frequently refer to other Civil Codes, including the $B G B$ and the Civil Codes of USSR and ČSSR. Since January 1953 the content of the theses had been discussed and revised. By mid-March 1953 the general editing of the General Section and the part on property rights was finished. This means that there was a complete draft of the first two parts of the planned $Z G B$. In the meeting on 4 May 1953 the sub-commission began the general editing of part 3 (general law of obligations). Although a further schedule for the next meetings had been set, the work stopped at this point. Therefore, we have only two complete preliminary drafts for the law of obligations, the general section and some chapters on particular obligations.

In May 1953 the SED gradually distanced themselves from the hard line of socialism (although, this did not help to avoid the revolution) which was related to codes for the GDR. On 9 June 1953, they voted for a "new course" towards a tempered building of socialism. When the work on a Civil Code restarted after the $S E D$ 's fifth party conference in 1958 the results from 1952/53 no longer played a role, but some personnel remained in their positions.

\section{"Structure and Guidelines for the Preparation of the Draft of the Civil Code"}

An extensive paper with the title Gliederung und Richtlinien für die Ausarbeitung des Entwurfes zum Zivilgesetzbuch (Structure and Guidelines for the Preparation of the Draft of the Civil Code) formed the basis of the work of the basic commission and subcommission on civil law. ${ }^{10}$ The author of this paper remains anonymous, but the paper provided an opinion on the motives for the creation of a new Civil Code and questions concerning the regulatory scope and structure of it. The discussion of the content emphasises the guidelines for the preparation of the first three parts of the code: general section, property law, general law of obligations.

\section{Why a New Civil Code?}

The paper explains that the creation of a new Civil Code was motivated by the fact that the abstract language of the $B G B$ is very difficult to understand. It "presents a barrier for the

\footnotetext{
8 See: die Protokolle im Bestand BA Berlin-Lichterfelde DP 2/5521.

9 Protokoll der Sitzung der Grundkommission von 22. September 1952, BA Berlin-Lichterfelde DP 2/5521 fol. 8 .

10 BA Berlin-Lichterfelde DP 2/5523, fol. $113 \mathrm{ff}$.
} 
development of the socialistic law of the GDR and therefore for the realization of the building of socialism". ${ }^{11}$ The old laws "disturb the consolidation of socialist legal order and hinder the development of full respect for our laws and the development of a socialistic state and legal consciousness". ${ }^{12}$ The paper argues that a new Civil Code is required "to emphasise the class objectives of the law". ${ }^{13}$ In contrast to this, the legal norms of the $B G B$ "did not convey the role of the socialistic state in its economic-organizational and cultural-educative function". ${ }^{14}$ This is how the new Civil Code accrued an ideological agenda. By doing so, the author refers to Ulbricht's objectives.

\section{Regulatory Content and Structure}

The new Civil Code was supposed to exclusively regulate citizens' financial circumstances and personal rights, such as naming, copyright law and the protection of honour. ${ }^{15}$ In contrast, the economic law was supposed to be a separate code. ${ }^{16}$ This hybrid field of law (not to be confused with the economic law, which had developed as a hybrid of civil law and public law in the Weimar Republic) developed during 1951 within the context of the system of comprehensive economic planning. It included, inter alia, "economic contracts" to realise plan fulfilment by the single economic entities. Those contracts had little to do with contracts under liberal civil law.

The civil law was not supposed to regulate family law or labour law. ${ }^{17}$ In fact, for those matters two special codes of law were planned, which had to be developed by the relevant subcommission. A code for land law, by contrast, was not planned. The result was the following structure of the planned code: Part one - general section, part two property law, part three - general rules on obligations, part four - particular obligations, part five - copyright law and publishing contract, part six - trademark law, part seven inheritance law. The individual parts were supposed to be divided into consecutively numbered chapters.

Apart from the absence of family law and the addition of part five and six, the new Civil Code had a standard structure, influenced by the pandectist school of law. The "general section", which probably would not have been very helpful for general comprehension of the code, reveals influences of the $B G B$. The similarity to Russian civil law is based on the fact that the Russian civil law is also influenced by the pandectist law school and that it also regulates family law and labour law in separate codes. The paper highlights the dependence on "the system of the RSFSR Civil Code, the first socialistic Civil Code in the world, developed under the guidance of W. I. Lenin, which illuminates our way by its

\footnotetext{
11 Gliederung und Richtlinien für die Ausarbeitung des Entwurfes zum Zivilgesetzbuch, BA Berlin-Lichterfelde DP 2/5523, fol. 113.

12 Ibidem.

13 Ibidem.

14 Ibidem.

15 Gliederung und Richtlinien für die Ausarbeitung des Entwurfes zum Zivilgesetzbuch, BA Berlin-Lichterfelde DP 2/5523, fol. 113f.

16 Gliederung und Richtlinien für die Ausarbeitung des Entwurfes zum Zivilgesetzbuch, BA Berlin-Lichterfelde DP 2/5523, fol. 114.

17 Ibidem
} 
precise directives and the outstanding precision in terms of formulation and which again and again proves its creative power". ${ }^{18}$

\section{General Section}

It has already been mentioned that a "general section" could not necessarily be expected. It seems, some commissioners were influenced by the $B G B$ and its abstract regulations - a system they had come to know and appreciate during their legal education. The ZGB's "general section" would not have been very different to the $B G B$ 's "general section”. Natürliche Personen (natural persons) are called Bürger (citizens) and Sachen (goods) had become Rechtsobjekte (legal objects). However, the chapters about "personal non-property-rights" and "guiding principles of the civil law" are new. The $B G B$ does not include a similar section about "guiding principles", but the Austrian $A B G B$ of 1812 (Von den bürgerlichen Gesetzen überhaupt, about the civil law in general"), the Russian Civil Code or the torso of a NS-Volksgesetzbuch of 1942, for example, do so.

In particular, the paper assigned a very fundamental function to the first chapter of the new Civil Code. It solidifies the constitution and accordingly contains "principles on the inviolability of socialistic state-owned property and on the meaning and role of socialistic state-owned property, on the socialistic cooperative property, on the private property, on the promotion of private working property, on the guarantee of private (capitalistic) ownership of the production means within the scope of the law". ${ }^{19}$ Regulations on the private ownership of production should be formulated to exclude the possibility of future legislation being affected. It appears that at this point they had future regulations that would be detrimental to private ownership in mind.

The project of creating regulations to protect "civil rights, unless they are exercised in contradiction to their socio-economic purpose", is no less important. ${ }^{20}$ Here the paper refers to the Soviet model, which differed fundamentally from capitalistic law, which is said to cover up the exploitative nature of the capitalistic economic system. These rules should "govern the jurisprudence on partiality in the interest of the construction of socialism". ${ }^{21}$ Thus, rules on the abuse of rights etc. "with their formal character" would become superfluous. ${ }^{22}$ This master-general clause subjects all private rights to a reservation of validity which comes from the contents of the prevailing ideology. Despite statements to the contrary, parallels to the development of jurisdiction in the years 1933-45, which led to a general abuse of rights-theory, after the jurisprudence of the Weimar years had generally remained within the framework drawn by the "formal character" of the rules of the $B G B$, are abundantly clear.

While the national socialistic judiciary, applying Sibert's model, increasingly placed all subjective rights under the reservation of validity in favour of the interests of the

18 Gliederung und Richtlinien für die Ausarbeitung des Entwurfes zum Zivilgesetzbuch, BA Berlin-Lichterfelde DP 2/5523, fol. 115 .

19 Gliederung und Richtlinien für die Ausarbeitung des Entwurfes zum Zivilgesetzbuch, BA Berlin-Lichterfelde DP 2/5523, fol. 121.

20 Ibidem.

21 Gliederung und Richtlinien für die Ausarbeitung des Entwurfes zum Zivilgesetzbuch, BA Berlin-Lichterfelde DP 2/5523, fol. 122 .

22 Ibidem. 
Volksgemeinschaft (national community), the judges in the GDR were to be given an explicit mandate of this kind to socialize the civil law in a very comprehensive manner. A very similar passage was planned for the introductory section of the national socialistic Volksgesetzbuch: "All rights shall be exercised in good faith and in accordance with the recognized national community life. The welfare of the community is to be put before one's own benefit." 23 In the opinion of the commission an elaboration of these principles in the form of theses was inappropriate at the time. ${ }^{24}$ As far as we can see, it has never happened.

\section{Property}

Law of goods (Sachenrecht) became property rights (Eigentumsrecht), because the directives rejected limited rights in property. These were meant to be legal relationships, which in the interest of the bourgeoisie were endowed with special protection and by their nature served to secure the basic pension. ${ }^{25}$ However, such legal relationships should, according to the plans, be included in the general part of the law of obligations under the heading "securing of obligations". The subcommission agreed to the elimination of these "old legal institutions inherited from feudalism" 26 and their incorporation into the law of obligations. It remains unclear, whether this also resulted in factual changes or whether it was just a propagandist or ideologically motivated systematic discontinuity.

The directives correctly define the chapter on the ownership of buildings as new. "It presupposes the repeal of $\S 93,94 B G B$, which by their nature served to secure the receipt of the basic pension. The measures of our state for the promotion of intelligence by building homes on national soil, the future measures for the promotion of the construction of homes for employees and workers, the enabling to construct cooperative buildings on private properties require the creation of the property right on buildings." 27 Admittedly, the paper mainly attributes "educational effect" 28 to this, because one must reverse the separation for private properties by the fact that these and the buildings can only be transferred or encumbered together.

Another chapter was planned to define the types of property rights including objects that "can be exclusively socialistic property under the applicable rules", whose "sole and unified owner" can be the "socialist state of the GDR". ${ }^{29}$ This seems to aim at two clear divergences compared to the existing civil law. On the one hand they wanted to incorporate

23 VGB-E Erstes Stück: Grundsätze des völkischen Gemeinschaftslebens, Ziffer 16.

24 DP 2/5521 fol. 17. Gliederung und Richtlinien für die Ausarbeitung des Entwurfes zum Zivilgesetzbuch, BA Berlin-Lichterfelde DP 2/5523, fol. 121. Gliederung und Richtlinien für die Ausarbeitung des Entwurfes zum Zivilgesetzbuch, BA Berlin-Lichterfelde DP 2/5523, fol. 122.

25 Gliederung und Richtlinien für die Ausarbeitung des Entwurfes zum Zivilgesetzbuch, BA Berlin-Lichterfelde DP 2/5523, fol. 116.

26 Sitzungsprotokoll der Grund- und Unterkommissionssitzung am 9. Oktober 1952, BA Berlin-Lichterfelde DP 2/5521, fol. 12 .

27 Gliederung und Richtlinien für die Ausarbeitung des Entwurfes zum Zivilgesetzbuch, BA Berlin-Lichterfelde DP 2/5523, fol. 116 f.

28 Gliederung und Richtlinien für die Ausarbeitung des Entwurfes zum Zivilgesetzbuch, BA Berlin-Lichterfelde DP 2/5523, fol. 117.

29 Gliederung und Richtlinien für die Ausarbeitung des Entwurfes zum Zivilgesetzbuch, BA Berlin-Lichterfelde DP 2/5523, fol. 128 . 
the extant regulations which considerably restrict private property into the new Civil Code. On the other hand, the dissolution of the property right, as it is regulated by the $B G B$ on the basis of ius commune; however, in progress nothing about this can be found, so that Hilde Benjamin suggests that it might refer to "Other forms of property?". 30

\section{General Regulations on Contractual Obligations}

The most striking part of the general part of the law of obligations is the chapter about securing of the contractual obligations. This is the chapter where limited property rights return. These had been removed from the property law (Eigentumsrecht). According to the working paper, the chapter aimed to regulate "the guarantee, the lien on movable objects and on rights and the lien on land (mortgage)". ${ }^{31}$ Furthermore, the working paper laid down that a particular non-possessory lien that would take the place of the chattel mortgage should be implemented. This means that they wanted to reverse the rejection from the traded chattel mortgage in favour of a security in the German Commercial Code (Allgemeines Deutsches Handelsgesetzbuch) and later in $\S 40$ Reichskonkursordnung, which took place in 19th century in Germany. Legal practice had reacted to the introduction of trade chattel mortgage with Sicherungsverkauf (preventive sale of the security) and chattel mortgage.

The first chapter of the general part of the law of obligations had a programmatic function. The working paper points out that "this chapter wants to establish general principles for the relation between socialist companies and between socialist companies and private economy by making clear the new content of the law of obligations. These principles have to be substantiated by model contracts, general terms of delivery et cetera. At the same time, concrete rulings for obligations where citizens are involved have to be met." 32 The list of subjects that have to be regulated was necessarily conventional: term, origin and types of contractual obligations. In this context at least acts of planning are mentioned as a reason for the origin of an obligation. The list fulfils the responsibility of the infringement of duties of contractual obligations et cetera: quality, place and time of performance. At first it cannot be said if the $Z G B$ would have found a general term for the violation of duties, because subsequently only culpability (intent, negligence, modification with creditors' default) and the responsibility for employees was listed. Hilde Benjamin is additionally referring to questions of causality in a marginal note. ${ }^{33}$ However, the common categories as impossibility or default are not mentioned. The only innovation is the removal of the "fourfold division of impossibility", because this, according to the paper, serves the concealment of the legal safeguarding of the capitalists' speculative actions. However, it was common opinion that these were not the best provisions of the $B G B$.

The abolishment of compensation for pain and suffering, which was meant to be a form of feudal wergild, was, however, new. As they saw it, with this compensation the

30 Gliederung und Richtlinien für die Ausarbeitung des Entwurfes zum Zivilgesetzbuch, BA Berlin-Lichterfelde DP 2/5523, fol. 128.

31 Gliederung und Richtlinien für die Ausarbeitung des Entwurfes zum Zivilgesetzbuch, BA Berlin-Lichterfelde DP 2/5523, fol. 117.

32 Gliederung und Richtlinien für die Ausarbeitung des Entwurfes zum Zivilgesetzbuch, BA Berlin-Lichterfelde DP 2/5523, fol. 134.

33 Ibidem. 
capitalist could buy himself free from the victim's right to go to court. ${ }^{34}$ The height of the compensation would always be an arbitrary decision. Instead of this arbitrariness, the penalty for negligent body injury should be higher. ${ }^{35}$ The right of compensation for damages is a field that the writers of the working paper wanted to radically simplify. They wanted to implement a norm that says that either the actual damage or at the same time the lost profit can be compensated. "With these two forms of the scope of compensation, the legal basis to ensure the ending of the chaos in civil jurisprudence about the right of compensatory damage, which would serve the concealment of class contents, is created." 36 Criticism of the confusing law of compensatory damages of the $B G B$ was and is, with or without a socialist point of view, justifiable. This means, that also in this field they simply strived for a simplification and improvement.

\section{Einzelne Schuldverhältnisse (Particular Obligations)}

The structure of the chapter about Einzelne Schuldverhältnisse (particular obligations) resembles the chapter on the same subject in the $B G B$. The working paper cannot be distinguished from the $B G B$; although it attributes great practical and also educational significance to the regulations about tort, ${ }^{37}$ the paper put them at the end of this chapter. It is notably at first sight, that here, types of contracts from the field of commercial law are included. As the $Z G B$ was not only intended to replace the $B G B$, but also the $H G B$, all types of contracts from the $H G B$ had to find their place in the $Z G B$. Some types of contracts that are regulated in the $B G B$, however, are missing. In general, contracts of any kind should be permitted, as long as they do not contradict the law and the interests of the socialist state. ${ }^{38}$

According to the working paper, the law of service and employment should contain general provisions on medical treatment contracts, contracts with a lawyer and other services. ${ }^{39}$ This would have meant the creation of a new law of contract for liberal professions. The "political and economic extraordinary important $M A S$-contract" 40 (machine rental contract) should, according to the paper, be regulated separately, because it was expected to underlie frequent changes. In the summer of the year 1948, for the first time, large farmers' agricultural machines were impounded. In 1949 the machine rental stations $(M A S)$ were created. These were responsible for taking the machines and lending them to small or new farmers.

Gliederung und Richtlinien für die Ausarbeitung des Entwurfes zum Zivilgesetzbuch, BA Berlin-Lichterfelde DP 2/5523, fol. 135.

35 Gliederung und Richtlinien für die Ausarbeitung des Entwurfes zum Zivilgesetzbuch, BA Berlin-Lichterfelde DP 2/5523, fol. 135 ..

36 Gliederung und Richtlinien für die Ausarbeitung des Entwurfes zum Zivilgesetzbuch, BA Berlin-Lichterfelde DP 2/5523, fol. 135 .

37 Gliederung und Richtlinien für die Ausarbeitung des Entwurfes zum Zivilgesetzbuch, BA Berlin-Lichterfelde DP 2/5523, fol. 118.

38 Gliederung und Richtlinien für die Ausarbeitung des Entwurfes zum Zivilgesetzbuch, BA Berlin-Lichterfelde DP 2/5523, fol. 119.

39 Ibidem.

40 Ibidem. 


\section{Law of Inheritance}

A far-reaching simplification of the law of inheritance was also planned. However, the legislative process stopped before they started work on it. The removal of the contract of inheritance, the renunciation of inheritance, and of sale of inheritance was planned. These legal institutions were seen as "typical for capitalistic law", ${ }^{41}$ as the only subject of the law of inheritance "is the line of succession in personal property of consumer goods and in private working property". ${ }^{42}$ However, implementing particular restrictions concerning the succession in capitalistic private property into the $Z G B$ was not considered politically advisable. ${ }^{43}$

The contract of inheritance between spouses and the joint testament of spouses became less important through the matrimonial property regime (separation of gains when the marriage is dissolved). A contractual bond between the spouses conflicted with the "nature of the socialist marriage". ${ }^{44}$ Contracts of inheritance with other persons would have a speculative character and therefore would not be permitted. The circle of persons appointed to succession should be restricted.

\section{Conclusion: New Wine in Old Tubes?}

The draft was strongly influenced by traditional civil law thinking. The idea of a civic codification of civil law had not been abandoned. Merely the application of such a codification in the service of socialism had been attempted. It was about creating a simple, practically usable law, not about the realization of the idea of an independent socialist concept of codification or an independent socialist civil law dogmatic. Thus, a very traditional codification of civil law had been drawn up which then had to be filled with socialist content. The norms' scope of application was limited by the framework of the constitution. So one had not detached oneself from civic jurisprudence, under which all members of the commission had grown up, but in fact one had detached from the civic social order.

\footnotetext{
41 Gliederung und Richtlinien für die Ausarbeitung des Entwurfes zum Zivilgesetzbuch, BA Berlin-Lichterfelde DP 2/5523, fol. 120.

42 Gliederung und Richtlinien für die Ausarbeitung des Entwurfes zum Zivilgesetzbuch, BA Berlin-Lichterfelde DP 2/5523, fol. 119.

43 Gliederung und Richtlinien für die Ausarbeitung des Entwurfes zum Zivilgesetzbuch, BA Berlin-Lichterfelde DP 2/5523, fol. 120 .

44 Ibidem.
} 